\title{
Sciendo
}

\section{Regulatory Framework of the Research-Based Approach to Education in the EU}

\section{Kristi Joamets Maria Claudia Solarte Vasquez}

Department of Law School of Business and Governance Tallinn University of Technology Akadeemia tee 3 Tallinn 12618, Estonia Email: kristi.joamets@taltech.ee Email: maria.solarte@taltech.ee

\begin{abstract}
Higher education institutions around the world have embarked on complex journeys of organizational change to facilitate the transition towards a more competent and educated society, especially one able to adapt to advanced and sustainable political, economic and sociotechnical paradigms. In this context, leading universities have adopted the Research-Based (RB) approach as a fundamental component of their strategies to bring closer together their main educational activities: teaching, learning and research. However, in spite of ample efforts, serious shortcomings at the implementation level are commonly reported. Especially revealing are the students' limited self-reliance, confidence, and academic research and writing skills documented in the literature. This article examines and updates the concept of Research-Based maps and explores the multilevel regulatory framework that has conditioned the implementation and alignment of educational initiatives, including the institutional arrangements that are common in public universities in the European Union, and in Estonia, as an example. It enhances the understanding of complex institutional and regulatory interactions in general, emphasizing the importance of reflexive and well justified normative determination.
\end{abstract}

Keywords: digital age education, educational policy, EU regulatory strategy, functional institutional analysis, researchbased education, research universities 


\section{Introduction}

Universities leading the transition towards a more competent and educated society in Europe, are interested in the Research-Based (RB) approach. The approach is endorsed by the European University Association (EUA) along with other key topics of the mission-enhancement agenda of the European universities, making the integration of research in teaching and learning an actively discussed priority at the national and institutional levels (European Forum for Enhanced Collaboration in Teaching, EFFECT 2016). There are virtually no published institutional assessments focusing on the RB approach addressing the quality of both the formal and informal regulatory environments, in spite of the crucial role they play in catalyzing strategic change and determining its successful implementation. This paper supplies educational public policy makers with an example that contributes to their strategic planning and design, by unpacking the institutional interactions that a number of future initiatives will have to tackle to respond to the complex demands of the times (e.g., reordering of educational facilities as smart and plugged into large digital ecosystem platforms (Uskov et al., 2017), absorption of a student population with virtually no homogeneous background, resetting of higher education goals for the digital and growingly automated economy, and in general, the creation of new models of education for the fourth industrial revolution (Selamat et al., 2017)). First, it examines the meaning of the RB concept to clarify the implications of a commitment involving this approach in higher education reforms, taking into account the regulatory framework and institutionalization processes in public universities in Europe and in Estonia, as an example.

EU policymakers and Member States' (MS) governments highlighted education, research, innovation and the modernization of higher education institutions among the most important pillars of the Lisbon Strategy more than a decade ago; these components are further integrated in the revamped Agenda 2020 of Europe (Gornitzka, 2007). The higher education units acquired crucial responsibilities in developing the continent's competitiveness within the knowledge-based economy but face obstacles that make them struggle to meet the stakeholders' expectations. There are institutionalization problems that have become apparent in this respect: regulatory fragmentation hindering the EU competitiveness on research, innovation and education, lack of organizational capabilities to compensate for the resulting misalignment, and weakness of the soft law alternatives to accelerate change. In addition, upon closer observation, the 
adoption and implementation of educational strategies in the public sector reveal additional hindrances at their operational levels, where the student population is directly involved. The COVID-19 pandemic has evidenced emerging and pressing educational needs. However, it could be expected that the student segments proficient in the $\mathrm{RB}$ approach have transitioned more smoothly to the independent, technology-mediated and self-directed educational formats that have come to replace the traditional educational methods.

Institutions are components of the essence of the social order. They may be represented in rules, strategies, paradigms, and are said to be "the embodiment of values in regularized (and relatively long lasting) patterns of behaviour" (Laswell, 1971 in Priscoli, 1989, p. 33). In this light, institutions in this article are understood as consolidated entities of shared beliefs and conventions that bond communities, operating in formal as well as informal realms outside purposive decision-making processes. Institutional studies are as current as ever, given the speed of technical, societal and economic change, and their influence in legislative development (Rutherford, 2016; Chochia \& Kerikmäe, 2020, p. 1). Institutions back up or regulate humanenvironment interactions, and they evolve and/or mediate social and organizational responses to environmental change.

The study examines the regulatory environment to identify and discuss the role that key formal and informal institutions play at the international, domestic and organizational levels, where recurring barriers, tensions, and hidden contradictions undermine policy strategies and implementation processes. It observes the sense-making (significance and meaning), collaborative (cohesive/aligned efforts to achieve certain social, political and economic objectives), and regulatory capacities of the framework on higher education, using a classical functional analysis approach (Downing et al., 1999). The assessment considers a selection of mainstream theories, orientations, practices, policies and laws, and looks for signs of the emergence of new ones.

This study makes the need for a more reflexive and responsive regulatory practice and purposeful development of institutional change initiatives in higher education understandable. It emphasizes that for public strategies to work in practice, clarity and alignment between theories, policy and regulation are indispensable. From the normative perspective, it exposes that the two conditions for an effective implementation of the $\mathrm{RB}$ approach to education are the consistent definition of the terms and scope of its activities, 
and precision in the assignation of the stakeholders' responsibilities at every level.

The next section summarizes the background on the meaning and use of the expression 'research-based' to characterize educational activities and the extent of its practice. Then follows an extended institutional review, focusing on policy and regulatory manifestations at the international, EU, state and university levels. This part describes the Estonian framework as an illustrative example. The third section looks into ways to catalyze the implementation of the RB approach at the managerial and operational levels and in the classroom. The last section concludes, restating the importance of clear and substantiated regulatory standards to support the development of functional educational models in the context explained, and others, even under different goals, such as the envisioned reskilling for the digital age.

\section{The RB approach}

The ideal of bringing teaching, learning and research closely together reflects an early nineteen-century school of thought led by Humboldt, a German philosopher who believed academics and students could pursue knowledge side by side, as co-researchers (Haverhals, 2007). In this view, the universities that encourage problem-solving techniques for learning and teaching may contribute in fundamental ways to building a better society and could be called research organizations. The European RB education models were shaped accordingly, and justified by a liberal understanding of the "useful mission" of knowledge that was closely related to the Enlightenment project, and grounded on broad social edification pursuits. Simons (2006) explains in detail the philosophical paradigm of Humboldt's arguments and the values attached to his notion of research and education. Nowadays, however, the expression 'research-based' is linked to an evolved and more pragmatic understanding of a wide range of academic activities.

A general consensus on the foundational importance of research exists among curricula developers in the institutions of higher education (Miller et al., 2012), but not on defining the concepts involved or on formulating an approach to effectuate their value. Students are still expected to join or form communities of thinkers by becoming able to reason, compare, differentiate, evaluate and find the truth scientifically following Newman's conception of a university (Dunne, 2006). At the same time, they are recipients that 
are placed at the centre of all educational related processes (Krahenbuhl, 2016). The inclusion of RB curricula in contemporary degree programmes indicates that students should learn as researchers, which according to Fung (2017, in Tong et al., 2018, p. 4), implies inquiring in active, critical and analytical ways. RB approaches in education are widely expected to stimulate, encourage and support students to acquire the knowledge, insights, attitudes and skills needed in advanced studies and professional careers (Giller, 2011). RB teaching and learning has been found to promote the students' interest and motivation (Wallin et al., 2017).

The literature shows that RB loosely characterizes some teaching and learning styles and methodologies, and suggests that research itself could be considered an epistemic goal (Berland et al., 2015). However, a proper determination of what exactly qualifies as research, how it is practiced and to which extent reaching academic aims may rely on that, is necessary to ground the formulation of consistent policies and educational strategies in public universities (Healey, 2005; Verburgh et al., 2013; Schouteden et al., 2016). Unclear understanding of this notion deprives the RB approach of meaning, making unattainable the academic accomplishments it is supposed to promote (Aditomo et al., 2013). Other functional denominations of educational activities calling for more precision at the prescriptive level are: 'research-engaged', 'inquiry-based', 'research oriented', 'students as researchers', etc. These expressions and the scope of common overarching phrases linked to research should be clarified.

Denotatively speaking, research is a systematic process of inquiry that relies on the collection, documentation, analysis and interpretation of data/ information. It is scientific when following rigorously selected methodologies (fit to purpose, according to the paradigm(s) of the discipline(s) concerned, etc.) (Patten \& Newhart, 2017). RB is the common denominator of teaching and learning activities in curricula for which the basic skill required is proficient, active and independent academic communication (in reading, writing and speaking). A differentiating factor is the degree of involvement and participation of the students.

Zamorski's work (2002) indicates that in educational interactions that are research-based and research tutored, the students are participative and are in control of their learning processes, whereas in the research-led and research-oriented interactions, they are more passive and dependent. While these latter types of activities presuppose that the study content reflects the state of the art and the research agenda of the discipline for which the 
students are the audience, the focus of the research-based and tutored ones is on "developing the students" ability to carry out research tasks themselves. The research tutored curricula also expects from the students and faculty the revision and discussion of topical matters, as well as being acquainted with the newest findings and the common practices in the given field (Healey \& Jenkins, 2009).

Where education in general is based on research (Research-Based Education, or RBE), the instructors and students are more willing to work independently and commit to do it systematically. The practice of research stimulates knowledge and is expected to increase the researchers' skills, confidence and interest (Healey et al., 2010). Hodson (1992) explains that students can learn from, about, and through research, when processing knowledge already produced within their fields, gaining understanding about the very production of knowledge, and at the same time, contributing to it. Overall, all the RB definitions of educational activities could be said to be processoriented, because they aim at securing effective learning experiences by promoting continuous research and being always in an inquiry mode (Healey et al., 2014, p. 42).

Research-Based Learning (RBL) falls under the contemporary participatory model of most higher education institutions. They include problem and project-based learning, hands-on work, and case study methods (Lambert, 2009). The students are inquirers and co-creators of knowledge in meaningful experiential settings. Healey and Jenkins (2009, p. 23) argue that RBL in undergraduate curricula must feature certain essential components such as discipline-specific methodologies, and respect for the convened directions about knowledge creation and dissemination in each study field, for example. To make RBL the standard has marked the mainstream trend in the field of educational reform worldwide, after the Boyer Report about reforming the undergraduate education in the United States was published (Katkin, 2003). This document states that "[i]nquiry-based learning, collaborative experience, writing and speaking expectations need to characterize the whole of a research university education", which was largely inspired by a claim made by John Dewey almost a century ago: "learning is based on discovery guided by mentoring rather than on the transmission of information" (Boyer Commission, 1998, p. 15).

Inquiry-based activities are also chief in the design of Research-Based Teaching (RBT) study programs, where learning is to take place in an environment where the roles of teachers and students are blurred. The 
research-led proposals within would still refer to the information transmission with a focus on the content matter (for instance, by understanding research outcomes)(Schapper \& Mayson, 2010), whereas the research-oriented understand the research "ethos" and concentrate on procedural knowledge: techniques and skills (Griffiths, 2004). In RBT the students also partake in instructive research processes.

The connection between attitudinal and cognitive effects of the RB approach should be acknowledged and studied in more detail to justify policy formulation and institutional change. For instance, the perspectives of motivation and learning theories, including the self-determination theory by Deci and Ryan (2012), and Martens and de Brabander's (2014), fit the RBE approach well, and would enrich the discussion about modelling interactions for the future of education.

\section{The institutional framework relevant to the RB approach}

The previous section reviewed the general understanding of research and RB activities and explained the nuanced meanings of the terms most commonly found in the literature. These refer to the sense-making dimension of the institutional assessment that explains the trends, justifies the emergence of principles, and informs policymaking, academic discourses and organizational development initiatives in the field. This is how research-based teaching, learning and/or education became commonplace in educational policy statements, university level development strategies, and curricula. Meaning is a decisive component of the emergence of informal institutions and institutionalization processes. The practice, in turn, legitimizes the functioning of the systems and its interactions, reinforcing their importance and leading sometimes to formalization via legislative procedures. In the following, some references to educational trends and aspirations replicated in policies introduce the legal framework that reflects the RB approach to education. The section is limited to some of the normative categories that are officially institutionalized as policies or laws at the international and supranational (EU) levels. In addition, the Estonian formal and informal regulatory environment is used to instantiate the review at the national level. 


\subsection{The RB approach at the EU level}

\subsubsection{Informal institutions}

The terms and expressions defined by the theory may be linked to the wider institutional context at the international and supranational levels. The inseparability of teaching and research is firmly established, among other principles and values of the European universities represented by the EUA, in the Magna Charta Universitatum (Observatory Magna Charta Universitatum, n.d.). The EUA declarations emphasize the importance of strengthening the link between the two activities, describing their teaching as research-inspired, research-based, or research-led. In the first European Learning and Teaching Forum organized by the EUA it was concluded that the models for the implementation of RBL strategies should emphasize learning by practicing, or the active acquisition of skills and knowledge through research. The working group in charge restated that RBL takes place when the students engage in inquiry and research through activities and processes that are part of the curricula, practicing problem/projectbased learning methodologies by default in all courses, and/or taking the specialized ones on research methodology (Loukkola \& Dakovic, 2017, p. 4). The group stressed the importance of fostering a more collaborative approach to education and an open-sharing knowledge culture.

The enhancement of research skills and embeddedness of research in both teaching and learning is at the top of the European universities' agenda. The EUA recommends permitting the participation of the students in projects related to the curricula content; implementing student-centred processes; "professionalising teaching"; and "training in RBE, problem solving, or experiential training" (Loukkola \& Dakovic, 2017). Similarly, the League of European Research Universities (LERU) promotes the interaction between basic research and education, assuming that research capacities develop primarily in educational environments, and that a close intertwining of teaching and research is important to strengthen the universities' identity, distinguishing them from other research and educational entities (LERU, 2002, p. 1).

The declarations seem up-to-date regarding educational trends; on the one hand, the opinions of experts and other informal institutions have influenced the EU policies on higher education, research and innovation. Education was recognized as an area of EU competency in the 1992 Treaty of Maastricht (Title XII, Art. 165(1) of the TFEU). On the other hand, they assume the existence 
of organizational capacities of the addressees to coordinate strategies that will result in social, political and economic benefits for the community. While according to the principle of subsidiarity, the governments, public higher education institutions and their managerial units in MS are entrusted to develop higher education policies and regulation in detail, the EU remit in the area is continuously expanding. It resorts to legal instruments such as decisions by the European Court of Justice, and to discursive instruments as the agenda setting communications issued by the European Commission. Technically, the EU formulates general guidelines on matters of education and social transformation issues (Communiction $\operatorname{COM}(2017) 247$ final) for the MS to be aware of the priorities and supported orientations in these fields. Moreover, the European Commission expects the active support of the universities of the European education ecosystem in developing the continent's competitiveness, for which the adequate regulatory framework and governance coordination with the direct involvement of national governments should be regarded as preconditions.

Education, research, innovation and the modernization of higher education institutions were among the pillars of the Lisbon Strategy of the EU (Soriano \& Mulatero, 2010), and even though the RB approach is not specifically mentioned, research, innovation, quality standards and competitiveness based on knowledge are fully integrated in the priorities of the Agenda 2020 of Europe (Gornitzka, 2007). Research is mentioned in dispersed documents and communications, mostly in connection to innovation, without defining its meaning or scope, or linked to general guidelines that add no precision.

Explaining the RB approach may not be a task that any supranationallevel organization should undertake. The Commission, however, has started to work more closely with state-level policymakers in the elaboration of higher education policies, and helps them adjust to its Education and Training 2020 strategy (European Commission, 2020). From the angle of classical functional institutional analysis, this supporting role demarcates the scope of the EU collaborative regulatory competences. The EU does not abandon it, but relies on other organisms and delegates responsibilities to achieve particular objectives. The renewed EU agenda for higher education identified four goals for European cooperation in this field, two of which could implicitly relate to research (Communication $\operatorname{COM}(2017) 247$ final). One refers to "tackling future skills mismatches and promoting excellence in skills development." It addresses findings on the students' lack of research skills reported in various commissioned studies, taking into account that these are among the most basic competences that could help foster knowledge 
generation and innovation, and employability, and that the Commission has been critical of systems where research "is not exploited enough as an input for teaching, undergraduates are often not involved in research, and their opportunities to explore contemporary issues and develop their research skills are limited" (Communication $\operatorname{COM}(2017) 247$ final, p. 5). The other goal is about helping universities to "contribute to innovation" with initiatives to advance organizational capabilities, such as the adoption of streamlined quality assurance mechanisms, and relying on the ground work already advanced with the Bologna process (Rauhvargers et al., 2009; Rasmussen et al., 2017).

The Commission fosters the concept of university networks and acknowledges their potential to encourage changes in educational practices through the coordinated planning of curricula and mobility. The Bologna process established the European Higher Education Area (EHEA), one of such international collaboration networks formed by 48 countries with different political, cultural and academic traditions on higher education (EHEA, n.d.). In the last twenty years, EHEA has been carrying out a common set of commitments and reforms, including the RBE challenges of linking education and research, and supporting research-based learning "in all cycles and disciplinary areas" (EHEA, 2015, p. 8). The universities within the EHEA are encouraged to systematize teaching, learning and research and make a better use of the synergies between these activities as the catalyzers they are in the development of critical thinking and creativity. The promotion of interdisciplinary programmes and the combination of academic and workbased learning in higher education were additional commitments that followed from the Paris communique (EHEA, 2018, p. 3).

Among the tools that EHEA uses in the implementation of the renewed EU agenda for higher education are the Standards and Guidelines for Quality Assurance (ESG) (see also Recommendation CM/Rec(2007)6). They reiterate that higher education is an "essential component of the socio-economic and cultural development" and that one of the chief aims of higher education is to stimulate research and innovation in creative ways, to fit the demands of the times (Standards and Guidelines for Quality Assurance, 2015, p. 6). The standards broadly cover learning, teaching and the environment in higher education that would be conducive to these purposes. They stress the importance of having policies and processes in place on the continuous improvement and monitoring of the quality of the research activities and education governance (Standards and Guidelines for Quality Assurance, 2015, p. 7). 
The same document recommends the policies to be made public and part of a wider and well-structured management strategy. In Section 1.1 it highlights the importance of the internal stakeholders' involvement and responsibilities that contribute to the quality assurance system: "departments, schools, faculties and other organizational units as well as those of institutional leadership, individual staff members and students" (Standards and Guidelines for Quality Assurance, 2015, p. 11). The guidelines are presented as the basis of coherent institutional systems with an increased level of accountability. The document mentions that policies are most effective when the relationship between research and learning \& teaching is evident and when the strategic approach matches the institutional context. The operationalization of the policy, its implementation and monitoring are decisions to be taken at the appropriate organizational levels. For instance, the universities are responsible in matters of competences and roles of the teaching staff, as well as in the creation of the proper environment that may support their effective performance (Standards and Guidelines for Quality Assurance, 2015, p. 13). The standards clearly indicate that in such an environment academic activities are to strengthen the links between education and research, and the guidelines suggest the establishment of the 'research-led' or 'research-oriented' educational approach (Standards and Guidelines for Quality Assurance, 2015, p. 15).

\subsubsection{Formal institutions}

Formal policies and legislation exist beyond the collaborative institutionalization initiatives noted above. The EU has formally recognized the role of the universities in its actions, documents, legislation and initiatives since the 1970s. Some legal texts with references to research and education and training were available even before these activities were covered by the European Community politics, but they lacked normative determination. The EU is still more likely to propose soft laws. While these allow more flexibility and fine tuning adjustments to societal and cultural needs, soft laws are too weak to persuade states to commit to legislative initiatives on institutional change. The same could be said to happen at other levels; policies and regulations are issued as guidelines for higher education institutions and organizations, without enforceable normative content. State interventions are not disallowed, but they take place when strictly necessary, and to the extent required, according to the principles of subsidiarity and proximity (Sin et al., 2016; Öberg, 2017). 
A number of functions that were once considered exclusive attributions of states are now the responsibility of public higher education institutions. They are encouraged to be more resolute, self-reliant and in some respects they are even supposed to ensure the effective application of the policies and general laws issued by the EU institutions and MS. With this autonomy and capacities, the universities have become regulators in their own right, able contribute to the development of the legal system in matters of their competence, independently and/or subscribing agreements with other entities (research institutions, think tanks, public bodies, agencies and organizations, companies, etc.).

\subsection{An MS example of the RB approach at the MS level}

A good example of a MS strongly committed to strengthen its human capital by creating, first and foremost, a strong standard on education and knowledge is Estonia. Like in other MS, the governance approach of the country operates issuing guiding policies and structuring regulations, under a traditional hierarchical structure that articulates the whole. While the guiding international principles are acknowledged, and educational theories are well known, the regulatory landscape of the country is highly formalistic. The practice is generally influenced by rules. Therefore, rather than a sharp differentiated review of informal and formal local institutions, here it is proper to present them as facets of a regulatory spectrum. In the less formal end are the Strategies on Higher Education 2006-2015 and Lifelong Learning 2020. The former stated that one of the directions of action is connecting teaching to research and development (Estonian Higher Education Strategy, 2006). The latter indicates that science is a key competence (Ministry of Education of Estonia, 2020a, p. 23). The draft of the most recent Education Development Plan 2021-2035 (Ministry of Education of Estonia, 2020b) observes that the RBL approach is not strong, which may be the reason why the new Estonian R\&D and Innovation Strategy 2021-2035 specifies that "science and high education should be better intertwined" and emphasizes that "research made in specific fields of high education ensures the quality of teaching" (Ministry of Education of Estonia, 2020b, p. 8).

Towards the more formal end, there are no explanations or detailed content about the RBE approach. The Estonian Constitution (1992), in its Articles 37 and 38, delineates the general principles of education without referring to any style of learning and teaching. Similarly, the Estonian Education Act (1992) refrains from detailing educational concepts, and the Regulation on 
the Standard of Higher Education (2019) uses the term "research" but does not orient the RBE approach or explain the RB concept.

The Higher Education Law Act (2019) speaks of research but separates it from learning. If we look at the Estonian legislation on higher education all together, one could conclude it does not relate research directly to any educational practice, or provide a complete normative base for the RBE. In contrast, the Quality Assessment of Study Programme Groups in the First and Second Cycles of Higher Education of the Estonian Quality Agency for High and Vocational Education (EKKA) elaborated (apparently assuming there is a general consensus) on the meaning of research as a creative activity that supports both, teaching and learning and demonstrates the students' involvement and participation (Estonian Higher Education Quality Assessment Council, 2012, p. 4). Study programmes are evaluated periodically, depending on the length of the authorization and on the basis of specific rules and criteria established for the institutions to conduct selfassessment reviews and evaluation reports.

The Self-evaluation Report of the Study Programme Groups in the First and Second Cycle of High Education inquires about RB teaching and learning activities in several instances: High Institution must give an overview of their research, development and/or other creative activity supporting teaching and learning, i.e., projects, applied research, publications, student involvement, etc. associated with the study programme group; and also on "how the supervision of student research papers is organized," "how involved are the students in the activities' set up," "how is teaching (courses, supervision, etc.) connected with the instructor's own research, or creative activities," and "how does research, development and/or the creative activities of the teaching staff enhance the quality of providing education according to the given study programme" (Estonian Higher Education Quality Assessment Council, 2012).

The EKKA's assessment criteria of the programmes may correspond to the expectations set by higher level policies, without contradicting the Estonian legal acts, but the official documents use terms related to RBE unsystematically, and they are not formulated as strict legal categories. This results in ambiguity, inconsistencies, and "responsibility bouncing", a situation that is likely to be occurring in other MS. When the State, educational institutions, faculties, staff and students are not clear about their roles, strategy planning, alignment and implementation are difficult to accomplish. It is reasonable to think that formal regulatory determination, 
nonetheless its implications, continue to be the most effective way to correct this disharmony.

A good start would be to endorse the more encompassing and dynamic expression of $\mathrm{RBE}$, because it is precise enough in regard to its characteristics but transferable, as it does not limit the style, focus or extent of its applications to any environment or academic activities in particular. RBE is to be specified at the discretion of policymakers, legislators and other regulators according to their needs, interests, and capabilities and adapt in time, but should be determined at the operational levels, for example, in the universities, for the proper training of the faculty, staff and students and application in the classrooms. The concepts that are common denominators of the RBE approach would be teaching and learning, and the basic skill required for both is proficient academic communication through reading, writing and speaking.

This section demonstrated that the degree of formality, consistency, and determination are variables that are useful not only for categorizing and characterizing institutions but also for anticipating their impact and applicability at the operational levels, that is, the university and/or the classrooms.

\section{Applications of the RB approach in the classrooms}

Institutions may be identified in the strategic normative/prescriptive sense at the managerial and the operational levels within organizations. As with every strategy, the planning and implementation of the RB approach and its replication would ideally allow the participation of the widest possible range of stakeholders, the engagement of members of the academic community, and representatives of the higher education institutions. The reason is the need for the whole community to convene in order to stimulate cooperation and adoption.

The behaviour of the faculty members, staff and students is governed by a myriad of institutionalized influences, but individuals innovate, create, and "deviate". Also, when the determination of strategies has been inadequate, it is likely that in the classroom even those instructors and students acquainted with research will be uncommitted to a single approach. This does not connote underperformance or failure to comply, but suggests structural 
(principles, standards, rules, guidelines, etc.) and procedural (techniques, training, monitoring, etc.) relaxation.

The stakeholders and institutions are interdependent and maintain a mutually constitutive relationship. Matthews et al. (2018, p. 27) observed that the strategies affect the roles and responsibilities of everyone directly involved in educational processes, be them managers, faculty, students or staff members. It could thus be stated that for a harmonious operationalization of the general supranational framework at the local and organizational layers and to disseminate the basic principles of the $\mathrm{RB}$ vision, engaging academics and researchers from within the EHEA, should be a priority.

Engaging in undergraduate research has been documented to improve and refine the students' research, writing, and collaboration skills (SpronkenSmith \& Walker, 2010; Kinkead, 2011; Walkington, 2015). Fung (2017, in Tong et al., 2018, p. 4) also explained the importance of implementing the $\mathrm{RBE}$ approach at all study levels. Given that research promotes creativity and sharpens people's ability to analyze, interpret, and synthesize information, and, that it helps to understand ethics in context (Kinkead, 2011, pp. 21-22), exposure to RB activities should start early. In spite of a strong consensus on the benefits of the RBE, there is no clarity on how these goals could align and where the exact standards and procedures to achieve them must be established. Could the implementation of supranational and national strategies be left to every university independently, or emerge from self-organizing processes? Should all academic instructors of every conceivable field be responsible for the students' development of basic academic literacies?

Academic professionals who teach and assess academic work (instructors of all levels, lecturers, curriculum developers, policymakers and researchers), are often exposed to the notorious lack of skills of students to produce appropriate academic content, especially in writing (Tardy, 2005; Maher et al., 2014). Not only is writing a precondition to be part of scientific projects, join teams and interact effectively in academic environments, but it is essential for authors to be part of discourse communities. In general, the ability to communicate by the use of discipline-specific and combined rhetoric and conventions is an important component of being part of highlevel interactions; research literacy and writing lay the foundations for the development of discipline-specific skills. Unfortunately, it is also known that many academic professionals have difficulties explaining the links between research objectives and learning, or do not have the incentives to do so, when 
it is not part of an institutional policy. They may lack the technical knowledge about educational processes or awareness regarding the expectations of the university.

It is hard to map institutions at this operational level relying on official data, because universities do not disclose in detail the result of their organizational assessments. It is not known what type of research is conducted and who participates, or whether the RBE approach has been tried and worked in practice.

Information is lacking about the stakeholders' perceptions of their own preparedness or expectations, [...] and much less of it is available regarding the effect of effective implementation of the $\mathrm{RB}$ approach in terms of knowledge creation, employability, institutional development, etc. The students, in average, indicate that their participation in research is limited, have not come to know much about the research of their teachers and did not feel included in the research community. (Van der Rijst et al., 2009, p. 223)

Van der Rijst, et al. (2009) published the results of their study a decade ago, but things have changed little. Still, empirical data to learn about the RB approach in practice, the adoption and processes of integration of research into curricula, and the effectiveness of implementation techniques, are hardly being collected.

The literature offers various examples of designs for $\mathrm{RB}$ teaching in study programs and individual courses showing how an RBE strategy is implemented in teaching. For example, in one of the first related studies on student writing tasks, Horowitz (1986, in Zhu, 2004) identified seven categories of those connected with research: summary of / reaction to a reading; annotated bibliography; participatory experiences report; connection of theory and data; case study; synthesis of multiple sources; and research projects. Visser-Wijnveen et al. (2010) reported that an ideal teaching-research nexus within individual courses should involve five teaching activities: (1) teaching research results, (2) making research known, (3) showing what it means to be a researcher, (4) helping to conduct research, and (5) providing research experience. The activities (4) and (5) would correspond to the denomination of 'research-based' teaching and curricula.

Healey and Jenkins (2009), Healey et al. (2014), and Walkington (2015; 2016) speak of other concrete techniques for research-based teaching and the best practices that support and sustain highly effective research environments. 
Some examples of research-based activities for students are: interviewing and reporting findings of other people's research; reading, studying and discussing scientific research articles, not only textbooks; writing reviews and briefing scientific studies, literature reviews; formulating hypotheses and research questions; developing research proposals; collecting and analysing data; participating in student research conferences; etc. Healey et al. (2014, p. 7) stated that "[e]ngaging students and staff effectively as partners in learning and teaching is arguably one of the most important issues facing higher education in the 21st century."

Parallel legal, political and economic concerns affect the operationalization of broad and undetermined strategies at the operational levels. Van der Rijst (2017) lists a few obstacles that undermine the RBE approach: first, in part because research productivity is at the core of many universities' developmental plans, teaching quality is not the top factor affecting tenure and promotion (also in Elen et al., 2007). A second obstacle is that the RB approach is very demanding on instructors, requiring them both to know how to motivate students and assist them in research (Gresty et al., 2013). However, good researchers are not necessarily good teachers or the other way around (Hajdarpasic et al., 2015, p. 644). Other significant challenges, mentioned by Simons (2006) and Simons and Elen (2007), are linked to the limited opportunities for continuing professional training that universities offer. The staff and faculty need support to update their competences, specifically in the field of RB teaching and curriculum development, if the university councils, faculty managers and educational directors promote such educational models (Elsen et al., 2009).

The setting of a general environment for effective teaching-research balance and some principles for people leading RBE developmental processes is uncommon but expected from higher education institutions. Barroga and Mitoma (2019) suggest the creation of a support system of instructors with strong area background and extensive experience in teaching, editing, writing and publishing to introduce the approach to others. Similarly, they recommend writing programmes, editing internships, academic courses on writing or research study designs and reporting standards, special interactive lectures, seminars, and academic visits, for the students to build their writing and publishing skills (Barroga \& Mitoma, 2019).

Research universities must equip the students with greater analytical abilities to add additional value to their careers, promote critical thinking, a systematic approach to learning and knowledge acquisition, and higher 
tolerance for uncertainty (Telfer, 2018). Telfer emphasizes the importance of allowing students to learn from their mistakes, and claims that some of the personal characteristics that research helps strengthen and could help the students' future professional performance are confidence, resilience, self-belief, and entrepreneurial attitude. The COVID-19 pandemic has put these traits to the test, but it will only be seen in its aftermath whether the faculty and students of higher education institutions used to RBE were better prepared and in control of the changing circumstances when teaching and learning had to migrate almost entirely to online environments. An RB approach to the design of curriculums, coupled with supporting technologies could soon become the standard for the proper administration of course content and delivery. This idea is not new-two decades ago, Edelson et al. (1999) had already pointed it out.

$\mathrm{RB}$ activities in the classrooms cultivate soft transferable skills such as problem solving and team work, and positive attitudes such as intellectual curiosity, persistence and a sense of attachment to a given discipline, faculty, and/or university (which are intrinsic motivation factors). More practically, they have become increasingly instrumental to the instructors when the research that they conduct is disseminated, project designs are brainstormed, and the students assist in data production, collection and processing. These purposeful interactions stimulate dialog and open discussions that may lead to interdisciplinary integration that helps disciplines flourish. Reciprocity is characteristic of $\mathrm{RB}$ activities in the classroom: academics learn from students (Wallin et al., 2017).

Table 1 shows some principles and activities that are common or of easy uptake at universities, particularly in Estonia, because of their compatibility with the overall institutional environment explained earlier. They are related to concrete techniques, and based on what scholars and experts such as Schapper and Mayson (2010) have proposed to address the obstacles and challenges identified.

Further empirical research could determine to which extent are these principles as well as other institutional manifestations brought to life, and whether they affect the teaching and learning experience of the instructors and students and the enhancement of their careers in the long run, across disciplines. The forecasted scenarios for the future of education are all digital and mediated by technology, requiring complex problem-solving abilities, creativity and new sets of socio-technical skills and responsibilities, for which the capabilities that the RBE approach promotes would still be foundational. 


\section{Table 1.}

\section{Principles to align research and teaching activities and the implementa- tion of RBE from the managerial to the classroom levels}

\begin{tabular}{|c|c|c|}
\hline $\begin{array}{l}\text { 1. Deciding and } \\
\text { communicat- } \\
\text { ing that teaching } \\
\text { and research are } \\
\text { equally important }\end{array}$ & $\begin{array}{l}\text { - Regulations } \\
\text { - Declarations, support and } \\
\text { guidance } \\
\text { Evidence-based curriculum } \\
\text { content, research-based and } \\
\text { oriented lectures, assignments } \\
\text { and outreach activities } \\
\text { (promote students participation } \\
\text { in academic events, } \\
\text { dissemination of results, etc.) }\end{array}$ & $\begin{array}{l}\text { - University } \\
\text { management } \\
\text { - Academic } \\
\text { management } \\
\text { - Faculty members }\end{array}$ \\
\hline $\begin{array}{l}\text { 2. Teaching and } \\
\text { learning hubs or } \\
\text { centres }\end{array}$ & $\begin{array}{l}\text { Study groups } \\
\text { Training and focused research } \\
\text { groups to study the faculty } \\
\text { practices and performance. } \\
\text { - Real-life cases and application } \\
\text { of the study content to solve } \\
\text { problems in the industry or } \\
\text { sector in question also in the } \\
\text { social sciences } \\
\text { - Get students involved in } \\
\text { research about their own per- } \\
\text { formance and academic needs. } \\
\text { Writing and editing services }\end{array}$ & $\begin{array}{l}\text { - Faculty management } \\
\text { - Faculty members } \\
\text { and students } \\
\text { - Faculty members, } \\
\text { staff and instructors } \\
\\
\text { - Faculty members, } \\
\text { staff and instructors, } \\
\text { students }\end{array}$ \\
\hline $\begin{array}{l}\text { 3. Appointment } \\
\text { of academics that } \\
\text { are excellent at } \\
\text { both teaching and } \\
\text { research }\end{array}$ & $\begin{array}{l}\text { - Training and holistic career } \\
\text { development support at } \\
\text { universities } \\
\text { - Transparent hiring and } \\
\text { attestation practices }\end{array}$ & $\begin{array}{l}\text { - Faculty and } \\
\text { academic } \\
\text { management } \\
\text { - University and } \\
\text { faculty management }\end{array}$ \\
\hline $\begin{array}{l}\text { 4. Wider allocation } \\
\text { of resources for } \\
\text { people interested } \\
\text { in research }\end{array}$ & $\begin{array}{l}\text { - Offering assistantship positions } \\
\text { to students and incentives for } \\
\text { performance in the field of } \\
\text { research (i.e., credits in ex- } \\
\text { change of data collection, and } \\
\text { processing, participation in con- } \\
\text { ferences and drafting of articles) } \\
\text { - Encouraging the use of leaning } \\
\text { exchange opportunities avail- } \\
\text { able from the bachelor level }\end{array}$ & $\begin{array}{l}\text { - University and } \\
\text { faculty manage- } \\
\text { ment, staff and } \\
\text { instructors }\end{array}$ \\
\hline 5. Recognition & $\begin{array}{l}\text { - Offering support and guidance, } \\
\text { or positions inside the faculty as } \\
\text { tutors or assistants, reciprocity } \\
\text { - Dissemination of good results of } \\
\text { instructors and students, } \\
\text { mentorship programs }\end{array}$ & $\begin{array}{l}\text { - Faculty management } \\
\text { - Instructors }\end{array}$ \\
\hline
\end{tabular}

Source: Compiled by the authors 


\section{Conclusion}

The close intertwining of research and other academic activities has been part of a greater initiative to strengthen Europe's identity and competitiveness. For that reason, the integration of research in teaching and learning is a priority at all institutional levels. This paper clarified the meaning of the $\mathrm{RB}$ concept to show what it implies for higher education reforms. It used a classical functional institutional analysis to map and explore the sensemaking, collaborative and regulatory capacities of the existing framework on higher education, and its influence in the strategic development of RBE in public universities inside the EU. At the MS and operational levels, Estonia was presented as an example where the RB strategy and implementation have not been well planned and coordinated.

From the normative perspective, the effective implementation of the RBE approach is shown to rest on two indispensable conditions: coherence and determination. While the former involves cohesive policies and regulation and consistent use of terms/concepts, the later demands precision in the assignation of the stakeholders' responsibilities (scope and range of activities that RBE should cover), at all levels. The success of public policies and educational strategies relies upon a smarter implementation effort of unified understandings and state regulatory processes in tandem with organizational and stakeholder coordinated action.

In the EU, institutionalization problems did not fully allow the realization of the higher education targets of the former Agenda 2020 of Europe. In this field, the EU plays a supporting role, because the more concrete policies are decided by the MS. This has resulted in regulatory fragmentation and indetermination. While countries issue contradictory or incomplete rules and no standards, the universities lack the capabilities and incentives to intervene and fix policy mismatches. The soft law alternatives to regulate strategic development have proven ineffective. The enhancement of educational activities and practices is left to the managerial bodies of higher education institutions to decide, which is not to be seen as a disadvantage. It allows them to pursue additional and differing organizational goals, if the resources or interest to invest on that are available.

To make the responsible implementation of policies and formal rules possible, along with other accountability demands, a basic legal framework and precision directed towards the public university development in 
Europe and in the MS is needed. The RB and RBE are to be specified by the regulatory actors keeping in mind the socio-technical requirements of the time, the interests of the public, and the capabilities of the organizational environment; the strategy should be dynamic, but defined enough, to make its operationalization possible, and inspire the training of the faculty, staff and students, and its use in the classroom. Much of the failure of educational policies is related to the inability of administrators to identify and define functions, priorities, tasks, and the stakeholders that should be in charge.

Functional institutional mapping and assessing is an indispensable preparatory step in planning regulatory strategies for complex systems like the EU, and in general to inform evolving regulatory affairs such as education. It could be combined with analytical models focused on the stakeholders to advance emerging inter-organizational arrangements entering the institutional arena, like an eventual 'Single Digital Governance Ecosystem of the EU' concerned with all conceivable regulatory dimensions and how to effect public policy. The article made the case for a more reflexive regulatory practice and the purposeful development of institutional change initiatives. This may also be key to smooth the transition to future reforms involving the technologymediated and AI-supported educational formats to come.

Kristi Joamets is a senior lecturer at Department of Law, Tallinn University of Technology. Dr Joamets has defended her doctoral degree (PhD) on public administration. She has more than 20 academic publications such as articles in peer-reviewed academic journals, chapters in books, and conference papers. Her main areas of research include family law, labour law, education law and social law.

Maria Claudia Solarte-Vasquez specializes in international contract law and transaction design. Her current research focuses on proactive law strategies and transitional pathways to legal automation. She conducted post-doctoral research at Aalto Business School (Finland), and is a visiting lecturer at the School of Business and Governance of Tallinn University of Technology (Estonia), where she completed her doctoral research $(\mathrm{PhD})$. 


\section{References}

Aditomo, A.; Goodyear, P.; Bliuc, A.-M. \& Ellis, R.C. (2013), 'Inquiry-based learning in higher education: principal forms, educational objectives, and disciplinary variations,' Studies in Higher Education, vol. 38, no. 9, pp. 1239-1258. https://doi.org/10.1080/03075079.2011.616584

Barroga, E. \& Mitoma, H. (2019), 'Improving scientific writing skills and publishing capacity by developing university-based editing system and writing programs,' Journal of Korean Medical Science, vol. 34, no. 1, pp. 1-8. https://doi.org/10.3346/jkms.2019.34.e9

Berland, L. K.; Schwarz, C. V.; Krist, C.; Kenyon, L.; Lo, A. S. \& Reiser, B. J. (2015), 'Epistemologies in practice: making scientific practices meaningful for students,' Journal of Research in Science Teaching, vol. 53, no. 7, pp. 1082-1112. https://doi.org/10.1002/tea.21257

Boyer Commission (1998), Reinventing Undergraduate Education: A Blueprint for America's Research Universities, Boyer Commission on Educating Undergraduates in the Research University, Stony Brook, NY: State University of New York at Stony Brook.

Chochia, A. \& Kerikmäe, T. (2020), 'Georgia on its path to Europeanisation: academic cooperation,' TalTech Journal of European Studies, vol. 10, no. 2, pp. 3-6. https://doi.org/10.1515/bjes-2020-0011

Communication from the Commission to the European Parliament, the Council, The Economic and Social Committee and the Committee of the Regions. On a renewed EU agenda for higher education, $\operatorname{COM(2017)~} 247$ final, 30.5.2017.

Consolidated version of the Treaty on the Functioning of the European Union, 2012/C 326/01, OJ C326/47, 26.10.2012.

Deci, E. L. \& Ryan, R. M. (2012), 'Motivation, personality, and development within embedded social contexts: An overview of self-determination theory,' in R. M. Ryan (ed.) The Oxford Handbook of Human Motivation, New York: Oxford University Press, pp. 85-107. https://doi.org/10.1093/oxfordhb/9780195399820.013.0006

Downing, T.; Garrido, A.; Giansante, C.; Iglesias, E.; del Moral, L.; Pedregal, G.; ... \& SIRCH Team (1999), A Framework for Institutional Analysis, ed. by K. Bakker, University of Oxford, Environmental Change Unit.

Dunne, J. (2006), 'Newman now: re-examining the concepts of 'philosophical' and 'liberal' in the idea of a university,' British Journal of Educational Studies, vol. 54, no. 4, pp. 412-428. https://doi.org/10.1111/j.1467-8527.2006.00347.x

Edelson, D. C.; Gordin, D. N. \& Pea, R. D. (1999), 'Addressing the challenges of inquiry-based learning through technology and curriculum design,' Journal of the Learning Sciences, vol. 8, nos. 3-4, pp. 391-450. https://doi.org/10.1080/10 508406.1999.9672075 
EFFECT (2016), [Home page], European Forum for Enchanced Collaboration in Teaching. Retrieved from https://eua.eu/101-projects/560-effect.html [accessed Nov 2020]

EHEA (n.d.), [Home page]. Retrieved from http://www.ehea.info/ [accessed Nov 2020] EHEA (2015), 'Yerevan Communiqué: The Bologna Process Revisited: The Future of the European Higher Education Area.' Ministerial Conference. Retrieved from http://www.ehea.info/media.ehea.info/file/2015_Yerevan/71/1/Bologna_ Process_Revisited_Future_of_the_EHEA_Final_613711.pdf [accessed Nov 2020]

EHEA (2018), 'Paris Communique.' Retrieved from http://www.ehea.info/media. ehea.info/file/2018_Paris/77/1/EHEAParis2018_Communique_final_952771. pdf [accessed Nov 2020]

Elen, J.; Lindblom-Ylänne, S. \& Clement, M. (2007), 'Faculty development in research-intensive universities: The role of academics' conceptions on the relationship between research and teaching,' International Journal for Academic Development, vol. 12, no. 2, pp. 123-139.

https://doi.org/10.1080/13601440701604948

Elsen, G. M. F.; Visser-Wijnveen, G. J.; van der Rijst, R. M. \& van Driel, J. H. (2009), 'How to strengthen the connection between research and teaching in undergraduate university education,' Higher Education Quarterly, vol. 36, pp. 64-85. https://doi.org/10.1111/j.1468-2273.2008.00411.x

Estonian Constitution (1992), Eesti Vabariigi Põhiseadus, Riigi Teataja, RT I, 15.05.2015, 2.

Estonian Education Act (1992), Eesti Haridusseadus, Riigi Teataja, RT I, 16.06.2020, 3 .

Estonian Higher Education Quality Assessment Council (2012), 'Quality Assessment of Study Programme Groups in the First and Second Cycles of Higher Education of the EKKA.' Retrieved from https://ekka.edu.ee/wp-content/uploads/Quality_ Assessment_SPG_11.11.2016.pdf [accessed Nov 2020]

Estonian Higher Education Strategy 2006-2015, Eesti kõrgharidusstrateegia, Riigi Teataja, RT I 2006, 52, 386.

European Commission (2020), Education and Training, European Policy Cooperation (ET 2020 Framework).

Giller, P. (2011), 'Integrating research into the undergraduate curriculum: a case study from Ireland,' Presentation at EUA Conference, Aarhus, April 2011.

Gornitzka, Å. (2007), 'The Lisbon process: a supranational policy perspective,' in P. Maassen \& J. P. Olsen (eds.) University Dynamics and European Integration, Dordrecht: Springer, pp. 155-178.

https://doi.org/10.1007/978-1-4020-5971-1_8 
Gresty, K. A.; Pan, W.; Heffernan, T. \& Edwards-Jones, A. (2013), 'Researchinformed teaching from a risk perspective,' Teaching in Higher Education, vol. 18, pp. 570-585. https://doi.org/10.1080/13562517.2013.795937

Griffiths, R. (2004), 'Knowledge production and the research-teaching nexus: the case of the built environment disciplines,' Studies in Higher Education, vol. 29, no. 6, pp. 709-726. https://doi.org/10.1080/0307507042000287212

Hajdarpasic, A.; Brew, A. \& Popenici, S. (2015), 'The contribution of academics' engagement in research to undergraduate education,' Studies in Higher Education, vol. 40, no. 4, pp. 644-657. https://doi.org/10.1080/03075079.2013.842215

Haverhals, B. (2007), 'The normative foundations of research-based education: philosophical notes on the transformation of the modern university idea,' Studies in Philosophy and Education, vol. 26, no. 5, pp. 419-432. https://doi.org/10.1007/s11217-007-9053-3

Healey, M. (2005), 'Linking research and teaching to benefit student learning,' Journal of Geography in Higher Education, vol. 29, no. 2, pp. 183-201. https://doi.org/10.1080/03098260500130387

Healey, M. \& Jenkins, A. (2009), Developing Undergraduate Research and Inquiry, York: The Higher Education Academy.

Healey, M.; Jenkins, A. \& Lea, J. (2014), Developing Research-Based Curricula in College-Based Higher Education, York: The Higher Education Academy.

Healey, M.; Jordan, F.; Pell, B. \& Short, C. (2010), 'The research-teaching nexus: a case study of students' awareness, experiences and perceptions of research,' Innovations in Education and Teaching International, vol. 47, no. 2, pp. 235-246. https://doi.org/10.1080/14703291003718968

Higher Education Law Act (2019), Kõrgharidusseadus, Riigi Teataja, RT I, 16.06.2020, 9 .

Hodson, D. (1992), 'An exploration of some issues relating to integration in science and science education,' International Journal of Science Education, vol. 14, no. 5, pp. 541-562. https://doi.org/10.1080/0950069920140506

Katkin, W. (2003), 'The Boyer Commission Report and its impact on undergraduate research,' New Directions for Teaching and Learning, vol. 93, pp. 19-38. https://doi.org/10.1002/tl.86

Kinkead, J. (2011), 'The impact of undergraduate research,' Newsletter for the Council of Fellows of the American Council on Education, vol. 33, no. 1, pp. 21-22.

Krahenbuhl, K. S. (2016), 'Student-centered education and constructivism: challenges, concerns, and clarity for teachers,' The Clearing House: A Journal of Educational Strategies, Issues and Ideas, vol. 89, no. 3, pp. 97-105. https://doi.org/10.1080/00098655.2016.1191311 
Lambert, C. (2009), 'Pedagogies of participation in higher education: a case for research-based learning,' Pedagogy, Culture \& Society, vol. 17, no. 3, pp. 295-309. https://doi.org/10.1080/14681360903194327

LERU (2002), The European Higher Education and Research Areas and the Role of Research-Intensive Universities. Retrieved from: https://www.leru.org/files/TheEuropean-Higher-Education-and-Research-Areas-and-the-Role-of-ResearchIntensive-Universities-Full-paper.pdf [accessed Nov 2020]

Loukkola, T. \& Dakovic, G., eds. (2017), EUA's Learning and Teaching InitiativeReport from the Thematic Peer Groups in 2017, Brussels: European University Association.

Maher, M. A.; Feldon, D. F.; Timmerman, B. E. \& Chao, J. (2014), 'Faculty perceptions of common challenges encountered by novice doctoral writers,' Higher Education Research \& Development, vol. 33, no. 4, pp. 699-711. https://doi.org/10.1080/07294360.2013.863850

Martens, R. L. \& de Brabander, C. J. (2014), 'Towards a unified theory of taskspecific motivation,' Educational Research Review, vol. 11, pp. 27-44. https://doi.org/10.1016/j.edurev.2013.11.001

Matthews, K. E.; Cook-Sather, A. \& Healey, M. (2018), 'Connecting learning, teaching and research through student-staff partnerships: towards universities as egalitarian learning communities,' in V. C. H. Tong, A. Standen \& M. Sotiriou (eds.) Shaping Higher Education with Students: Ways to Connect Research and Teaching, London: UCL Press, pp. 23-29. https://doi.org/10.2307/j.ctt21c4tcm.7

Miller, A.; Sharp, J. \& Strong, J., eds. (2012), What is Research-Led Teaching? Multi-Disciplinary Perspectives, London: Consortium for Research Excellence, Support and Training (CREST).

Ministry of Education of Estonia (2020a), Eesti elukestva oppe strateegiad [Estonian strategies of lifelong learning]. Retrieved from https://www.hm.ee/sites/default/ files/strateegia2020.pdf [accessed Nov 2020]

Ministry of Education of Estonia (2020b), Haridusvaldkonna arengukava 2021-2035 [Higher education strategy 2012-2035]. Retrieved from https://www.hm.ee/sites/ default/files/eesti_haridusvaldkonna_arengukava_2035_seisuga_2020.03.27. pdf [accessed Nov 2020]

Öberg, J. (2017), 'Subsidiarity as a limit to the exercise of EU competences,' Yearbook of European Law, vol. 36, pp. 391-420. https://doi.org/10.1093/yel/yew027

Observatory Magna Charta Universitatum (n.d.), 'Living values in high education institutions. Prospectus.' Retrieved from: http://www.magna-charta.org/ activities-and-projects/living-values-project [accessed Nov 2020]

Patten, M. L. \& Newhart, M. (2017), Understanding Research Methods: An Overview of the Essentials, New York: Taylor \& Francis.

https://doi.org/10.4324/9781315213033 
Priscoli, J. B. (1989), 'Public involvement, conflict management: means to EQ and social objectives,' Journal of Water Resources Planning and Management, vol. 115, no. 1, pp. 31-42. https://doi.org/10.1061/(ASCE)0733-9496(1989)115:1(31)

Rasmussen, J. S.; Hørsted, A. \& Nygaard, C. (2017), 'The Bologna Process as a possible driver for the globalisation of HE?' in Globalisation of Higher Education: Political, Institutional, Cultural, and Personal Perspectives, Faringdon: Libri Publishing Ltd, pp. 17-34.

Rauhvargers, A.; Deane, C. \& Pauwels, W. (2009), Bologna Process Stocktaking Report, Report from working groups appointed by the Bologna Follow-up Group to the Ministerial Conference in Leuven/Louvain la Neuve, April 2009. Retrieved from http://ehea.info/media.ehea.info/file/20090326-27-Prague/61/0/ BFUG_CZ_16_5.1a_stocktaking_final_594610.pdf [accessed Nov 2020]

Recommendation CM/Rec(2007)6 by the Council of Europe's Committee of Ministers on the public responsibility for higher education and research, 16.5.2007.

Rutherford, A. (2016), 'The effect of top-management team heterogeneity on performance in institutions of higher education,' Public Performance \& Management Review, vol. 40, no. 1, pp. 119-144.

https://doi.org/10.1080/15309576.2016.1177559

Schapper, J. \& Mayson, S. E. (2010), 'Research-led teaching: moving from a fractured engagement to a marriage of convenience,' Higher Education Research \& Development, vol. 29, no. 6, pp. 641-651.

https://doi.org/10.1080/07294360.2010.489236

Schouteden, W.; Verburgh, A. \& Elen, J. (2016), 'Teachers' general and contextualised research conceptions,' Studies in Higher Education, vol. 41, no. 1, pp. 79-94. https://doi.org/10.1080/03075079.2014.914915

Selamat, A.; Alias, R. A.; Hikmi, S. N.; Puteh, M. \& Tapsi, S. M. (2017), 'Higher education 4.0: Current status and readiness in meeting the fourth industrial revolution challenges,' Redesigning Higher Education towards Industry, vol. 4, pp. 23-24.

Simons, M. (2006), “Education through research' at European universities: notes on the orientation of academic research,' Journal of Philosophy of Education, vol. 40, no. 1, pp. 31-50. https://doi.org/10.1111/j.1467-9752.2006.00493.x

Simons, M. \& Elen, J. (2007), 'The 'research-teaching nexus' and 'education through research': An exploration of ambivalence,' Studies in Higher Education, vol. 32, pp. 617-631. https://doi.org/10.1080/03075070701573781

Sin, C.; Veiga, A. \& Amaral, A. (2016), 'European higher education policies,' in European Policy Implementation and Higher Education, London: Palgrave Macmillan, pp. 41-62. https://doi.org/10.1057/978-1-137-50462-3_3 
Soriano, F. H. \& Mulatero, F. (2010), 'Knowledge policy in the EU: From the Lisbon strategy to Europe 2020, Journal of the Knowledge Economy, vol. 1, no. 4, pp. 289-302. https://doi.org/10.1007/s13132-010-0020-9

Spronken-Smith, R. \&Walker, R. (2010), 'Can inquiry-based learning strengthen the links between teaching and disciplinary research?' Studies in Higher Education, vol. 35, no. 6, pp. 723-740. https://doi.org/10.1080/03075070903315502

Standard of Higher Education (2019), Kõrgharidusstandard, Riigi Teataja, RT I, 12.07.2019, 17 .

Standards and Guidelines for Quality Assurance in the European Higher Education Area (ESG) (2015), Brussels, Belgium.

Uskov, V. L.; Bakken, J. P.; Penumatsa, A.; Heinemann, C. \& Rachakonda, R. (2017), 'Smart pedagogy for smart universities,' in International Conference on Smart Education and Smart E-Learning, Cham: Springer, pp. 3-16.

https://doi.org/10.1007/978-3-319-59451-4_1

Tardy, C. M. (2005), “It's like a story”: rhetorical knowledge development in advanced academic literacy,' Journal of English for Academic Purposes, vol. 4, no. 4, pp. 325-338. https://doi.org/10.1016/j.jeap.2005.07.005

Telfer, R. A., ed. (2018), Aviation Instruction and Training, London: Routledge. https://doi.org/10.4324/9780429463273

Tong, V. C.; Standen, A. \& Sotiriou, M., eds. (2018), Shaping Higher Education with Students: Ways to Connect Research and Teaching, London: UCL Press. https://doi.org/10.2307/j.ctt21c4tcm

Van der Rijst, R. (2017), 'The transformative nature of research-based education: A thematic overview of the literature,' in Research-Based Learning: Case Studies from Maastricht University, Cham: Springer, pp. 3-22.

https://doi.org/10.1007/978-3-319-50993-8_1

Van der Rijst, R. M.; Visser-Wijnveen, G. J.; Verstelle, T. \& Van Driel, J. H. (2009), 'Studentbeleving van de onderzoekintensiviteit van universitaire onderwijsomgevingen,' Pedagogische Studiën, vol. 86, pp. 214-229.

Verburgh, A. L.; Schouteden, W. \& Elen, J. (2013), 'Patterns in the prevalence of research-related goals in higher education programmes,' Teaching in Higher Education, vol. 18, no. 3, pp. 298-310.

https://doi.org/10.1080/13562517.2012.719153

Visser-Wijnveen, G. J.; Van Driel, J. H.; Van der Rijst, R. M.; Verloop, N. \& Visser, A. (2010), 'The ideal research-teaching nexus in the eyes of academics: building profiles,' Higher Education Research \& Development, vol. 29, no. 2, pp. 195-210. https://doi.org/10.1080/07294360903532016

Walkington, H. (2015), Students as Researchers: Supporting Undergraduate Research in the Disciplines in Higher Education, York: The Higher Education Academy. 
Walkington, H. (2016), 'Students as researchers, students as authors: strategies for engaging students in research and dissemination,' Presentation at the 7th Innovation Room on 'Investigative Learning' of the Centre for Education and Learning on 11 November. Retrieved from http://www.educationandlearning. nl/news/cel-innovation-room-7-investigative-learning [accessed Nov 2020]

Wallin, P.; Adawi, T. \& Gold, J. (2017), 'Linking teaching and research in an undergraduate course and exploring student learning experiences,' European Journal of Engineering Education, vol. 42, no. 1, pp. 58-74. https://doi.org/10.1080/03043797.2016.1193125

Zamorski, B. (2002), 'Research-led teaching and learning in higher education: a case,' Teaching in Higher Education, vol. 7, no. 4, pp. 411-427. https://doi.org/10.1080/135625102760553919

Zhu, W. (2004), 'Faculty views on the importance of writing, the nature of academic writing, and teaching and responding to writing in the disciplines,' Journal of Second Language Writing, vol. 13, no. 1, pp. 29-48.

https://doi.org/10.1016/j.jslw.2004.04.004 